\title{
Potential return on investment of a family- centered early childhood intervention: a cost-effectiveness analysis
}

Negin Hajizadeh ${ }^{1 *}$, Elizabeth R. Stevens², Melanie Applegate², Keng-Yen Huang², Dimitra Kamboukos²,

R. Scott Braithwaite ${ }^{2}$ and Laurie M. Brotman ${ }^{2}$

\begin{abstract}
Background: ParentCorps is a family-centered enhancement to pre-kindergarten programming in elementary schools and early education centers. When implemented in high-poverty, urban elementary schools serving primarily Black and Latino children, it has been found to yield benefits in childhood across domains of academic achievement, behavior problems, and obesity. However, its long-term cost-effectiveness is unknown.

Methods: We determined the cost-effectiveness of ParentCorps in high-poverty, urban schools using a Markov Model projecting the long-term impact of ParentCorps compared to standard pre-kindergarten programming. We measured costs and quality adjusted life years (QALYs) resulting from the development of three disease states (i.e., drug abuse, obesity, and diabetes); from the health sequelae of these disease states; from graduation from high school; from interaction with the judiciary system; and opportunity costs of unemployment with a lifetime time horizon. The model was built, and analyses were performed in 2015-2016.
\end{abstract}

Results: ParentCorps was estimated to save $\$ 4387$ per individual and increase each individual's quality adjusted life expectancy by 0.27 QALYs. These benefits were primarily due to the impact of ParentCorps on childhood obesity and the subsequent predicted prevention of diabetes, and ParentCorps' impact on childhood behavior problems and the subsequent predicted prevention of interaction with the judiciary system and unemployment. Results were robust on sensitivity analyses, with ParentCorps remaining cost saving and health generating under nearly all assumptions, except when schools had very small pre-kindergarten programs.

Conclusions: Effective family-centered interventions early in life such as ParentCorps that impact academic, behavioral and health outcomes among children attending high-poverty, urban schools have the potential to result in longer-term health benefits and substantial cost savings.

Keywords: Markov model, ParentCorps, Childhood, Obesity, Behavior problems

\section{Background}

ParentCorps is a family-centered enhancement to prekindergarten (pre-k) programming that aims to promote family engagement and safe, nurturing and predictable environments at home and at school. When implemented in high-poverty, urban schools serving primarily Black and Latino pre-k students, it has been found to yield robust and sustained benefits through age 8 across

\footnotetext{
* Correspondence: nhajizadeh@northwell.edu

'Department of Medicine, Zucker School of Medicine at Hofstra/Northwell,

300 Community Drive, Manhasset, NY 11030, USA

Full list of author information is available at the end of the article
}

domains of academic achievement, behavior problems, and obesity [1-5]. There is a substantial body of developmental and experimental evidence that early childhood learning, behavior and health problems cascade to predict costly and impairing life-long disorders and conditions. We sought to estimate the long-term costeffectiveness of ParentCorps for children attending pre-k programs in high-poverty, urban schools.

Two randomized controlled trials (RCTs) in 18 high-poverty, urban schools with more than 1200 Black and Latino children provide the evidentiary foundations for ParentCorps' impact on child health 
and development [1-5]. The second trial enrolled nearly $90 \%$ of the pre-k population $(n=1050)$ and intent-to-treat analysis documents impact through second grade on mental health (behavior and emotional problems) and academic achievement (teacherrated performance and reading achievement test scores) across baseline levels of self-regulation in prek (e.g., impulsivity, inattention, hyperactivity). In addition, among the subgroup of pre-k students with low self-regulation ( $\sim 25 \%$ of the pre-k population in high-poverty, urban schools), ParentCorps in pre-k led to substantially lower rates of obesity (defined as BMI $\geqq 95$ th percentile) and sedentary behavior through second grade [2-5].

Longitudinal and experimental studies that follow children from early childhood into adulthood provide strong support for a cascading developmental model to explain drug abuse, antisocial behavior and interaction with the judiciary system. For example, a large prospective study of public school children [6] identified a developmental pathway starting in early childhood and resulting in substance abuse in 12th grade. Children who experienced seven risk factors over time (i.e., poverty, low self-regulation in early childhood, early parenting problems, early behavior problems, early peer problems, adolescent parenting problems, and adolescent peer problems) had a 91\% chance of using illicit substances by 12th grade, compared with a population base rate of $51 \%$. An experimental study in high-poverty, urban schools found that intervention early in elementary school prevented poor health outcomes. By ages 19 to 21, boys receiving the intervention, particularly those who entered school with behavior problems, reported significantly reduced rates of tobacco use, substance use problems and antisocial personality disorders [7].

Although there are no long-term follow-up studies of early childhood obesity prevention, children who are overweight or have obesity in early childhood are five times more likely to be overweight or have obesity as adults [8]. Therefore, an intervention such as ParentCorps that effectively reduces rates of childhood obesity and sedentary behavior would be expected to have longterm impact on adult obesity and related health behaviors [4]. In fact, three recent, independent mathematical simulation models (cost-effectiveness analyses) found that early obesity reduction in childhood and adolescence would be cost effective, due to reductions in the number of adults with obesity, lifetime medical costs and increases in quality-adjusted life years (QALYs) by the age of 40 [9-11].

Based on ParentCorps' documented effects on academic achievement, behavior problems, and obesity, and a substantial developmental literature, we designed a mathematical model to project the impact of ParentCorps as an enhancement to pre- $k$ in high-poverty, urban schools on life-long costs and health (life expectancy and QALYs), as compared to standard pre-k programming.

\section{Methods}

We designed a Markov model using TreeAgePro software [12] to represent the lifespan of an individual transitioning from the end of the pre-k year ( age 5) through childhood, adolescence and adulthood, following either exposure to ParentCorps in pre-k, or standard pre-k programming. A hypothetical child enters the model at age 5 years and, after exposure or no exposure to ParentCorps, transitions through different possible scenarios year by year after graduation from high school and into adulthood until death. What happens to the individual from childhood through adulthood is aggregated into a calculation of life expectancy and quality of life. QALYs are the most commonly used form of health-adjusted life years, [13] which encapsulate the idea that a year spent in good health is fundamentally worth more than a year spent in poor health. The model was used to simulate 100,000 hypothetical individuals and has a lifetime time horizon. The model was built and analyses were performed in 2015-2016.

\section{Model structure}

The structure of the model was guided by an influence diagram that reflects interrelationships of important constructs found to be changed by ParentCorps in childhood, and may be impacted by ParentCorps in adolescence and adulthood (Fig. 1). Specifically, ParentCorps promotes academic achievement and prevents behavior problems across all levels of pre-k self regulation and prevents obesity among children with low self-regulation [2-4]. The anticipated cascading effects of these documented childhood benefits are represented in the model. The model is divided into a childhood phase (including adolescence), which ends at age 18 (typical age of graduation from high school), and an adulthood phase, which follows the individual until death. The childhood phase records whether the youth develops behavior problems, abuses drugs, develops obesity, develops diabetes, achieves academically, and graduates from high school. The youth then transitions into adulthood and has a subsequent trajectory influenced by the childhood pathway.

The model is a state-transition simulation that employs "Markov states," which represent different ways of "being" in a given time cycle. The Markov states include the combination of different health states (i.e., obesity, diabetes, and drug abuse) and their health sequelae (i.e., 


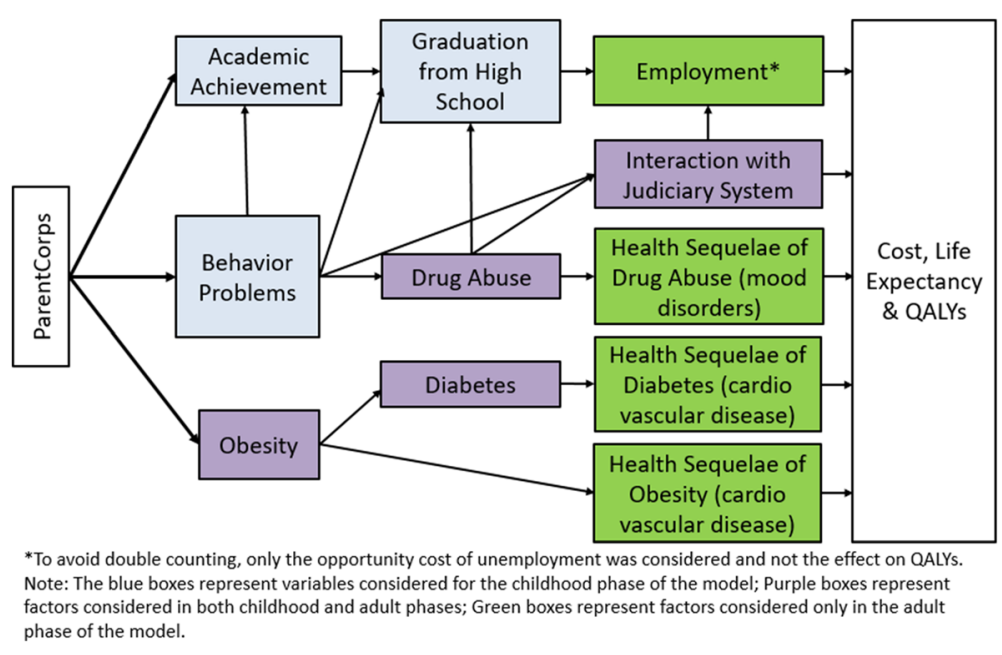

Fig. 1 Influence diagram. Influence diagram showing the constructs embedded in the mathematical model

cardiovascular disease and psychiatric disorders); whether the hypothetical person is employed; and whether the person has an interaction with the judiciary system in a given year. To keep the model tractable and focused on the predicted longer-term effects of early intervention into adulthood, the childhood phase has only one Markov state and a time cycle of 13 years (i.e., pre-k through end of high school). The adult phase has 32 Markov states and a time cycle of 1 year. These Markov states in adulthood depend on five attributes: 1) obesity and/or health sequelae of obesity; 2) diabetes and/or health sequelae of diabetes; 3) drug abuse and/or health sequelae of drug abuse; 4) interaction with the judiciary system; and 5) employment.

The model was designed to emphasize three particularly important pathways in the influence diagram: 1) lack of basic academic proficiency (achievement) may lead to decreased employment; 2) behavior problems may lead to drug abuse and its health sequelae, and interaction with the judiciary system; and 3) obesity may lead to diabetes and its health sequelae. In the model, academic proficiency and behavior problems influence the likelihood of graduating from high school, which ultimately impacts the likelihood of employment. Behavior problems also influence the likelihood of drug abuse. Together with drug abuse, behavior problems also influence the likelihood of interaction with the judiciary system. The model represents whether a child with low self-regulation in pre- $k$ achieves academic proficiency, develops behavior problems and/or obesity, and the impact of ParentCorps in promoting academic achievement and preventing behavior problems and/or obesity, especially among children with low self-regulation. The increased likelihood of youth with obesity developing type-2 diabetes, and its long-term health sequelae (e.g., cardiovascular disease) are also reflected in the model. Finally, employment, interaction with the judiciary system, and health sequelae of drug abuse and/or diabetes influence the outcomes that are tracked by the model (i.e., costs, life expectancy, and qualityadjusted life expectancy).

\section{Data inputs}

Data inputs (Table 1) were obtained from the peerreviewed scientific literature including reports by Brotman and colleagues from RCTs of ParentCorps' impact in childhood [1-5]. Where available, odds and odds ratios were the preferred metric used to determine likelihoods of events. When these metrics were not directly available, they were backcalculated from incidence rates and/or prevalence estimates, assuming uniform incidence rates over time. Plausible ranges for each estimate were determined by the $95 \%$ confidence intervals, or, if unavailable, by consulting with content area experts. Where necessary, we used decision rules to pool relevant data using the random effects method of DerSimonian and Laird, and tested for homogeneity defined as a Q-statistic of $>0.10$, I-statistic of $<25 \%$ and a $p$-value of $<0.05$ with no significant outliers on the Forest plot [14]. If data were not homogeneous, the median value was used and the plausible range included the lowest and highest reported confidence intervals. Mortality data were obtained from the Centers for Disease Control 2008 National Vital Statistic Report and from disease specific mortality rates [15-17]. 
Table 1 Model inputs

\begin{tabular}{|c|c|c|c|c|c|c|}
\hline Variable & $\begin{array}{l}\text { Inputs } \\
\text { (Odds) }\end{array}$ & $\begin{array}{l}\text { Notable assumptions } \\
\text { and explanations }\end{array}$ & $\begin{array}{l}\text { Lower } \\
\text { range }\end{array}$ & $\begin{array}{l}\text { Upper } \\
\text { range }\end{array}$ & Source population & References \\
\hline \multicolumn{7}{|l|}{ Inputs influencing health } \\
\hline \multicolumn{7}{|l|}{ Child Specific } \\
\hline $\begin{array}{l}\text { Odds ever of good } \\
\text { academic achievement } \\
\text { (basic academic proficiency) }\end{array}$ & 1.35 & $\begin{array}{l}\text { Fixed prevalence throughout } \\
\text { childhood based on a point } \\
\text { prevalence ( } 4 \text { th-12th grade) } \\
\text { of } 57.5 \% \text { basic academic } \\
\text { achievement }\end{array}$ & 0.7 & 2.0 & $\begin{array}{l}\text { National 4th grade black public } \\
\text { school students }\end{array}$ & {$[33]$} \\
\hline $\begin{array}{l}\text { Odds ever of obesity as a } \\
\text { child (BMl at or above } 95 \% \text { ) }\end{array}$ & 0.146 & $\begin{array}{l}\text { Assumed a cumulative incidence } \\
\text { of } 23.8 \% \text { by age } 10 \text { ( } 5 \text { th grade) } \\
\text { based on a point prevalence } \\
\text { of } 23.8 \% \text { (K-5th grade) }\end{array}$ & 0.09 & 0.3 & $\begin{array}{l}\text { NYC public elementary school } \\
\text { students }\end{array}$ & {$[34]$} \\
\hline $\begin{array}{l}\text { Odds ever of low self- } \\
\text { regulation }\end{array}$ & 0.33 & $\begin{array}{l}\text { Fixed prevalence throughout } \\
\text { childhood based on a period } \\
\text { prevalence of } 25 \%\end{array}$ & 0.15 & 0.4 & $\begin{array}{l}\text { High risk children followed infancy } \\
\text { through grade } 3\end{array}$ & {$[5,28]$} \\
\hline $\begin{array}{l}\text { Odds ever that a child will } \\
\text { behavior problems }\end{array}$ & 0.275 & $\begin{array}{l}\text { Fixed prevalence throughout } \\
\text { childhood based on a period } \\
\text { prevalence of } 21.6 \%\end{array}$ & 0.14 & 0.4 & $\begin{array}{l}\text { Kindergarten or first grade students } \\
\text { given any early poverty }\end{array}$ & {$[29]$} \\
\hline $\begin{array}{l}\text { Odds of graduating from } \\
\text { high school }\end{array}$ & 2.125 & $\begin{array}{l}\text { One-time event, estimated from } \\
\text { incidence of } 68 \%\end{array}$ & 1.59 & 2.66 & $\begin{array}{l}\text { Low-income New York state high } \\
\text { school students }\end{array}$ & {$[35]$} \\
\hline $\begin{array}{l}\text { Odds of any drug abuse } \\
\text { disorder }\end{array}$ & 0.13 & $\begin{array}{l}\text { Fixed prevalence throughout } \\
\text { childhood based on a point } \\
\text { prevalence of } 11.4 \%\end{array}$ & 0.11 & 0.15 & $\begin{array}{l}\text { Nationally representative face-to-face } \\
\text { survey of adolescents aged } 13 \text { to } \\
18 \text { years in the continental } \\
\text { United States. }\end{array}$ & {$[50]$} \\
\hline $\begin{array}{l}\text { Odds ever of type } 2 \\
\text { diabetes as a child }\end{array}$ & 0.001 & $\begin{array}{l}\text { Fixed prevalence throughout } \\
\text { childhood based on a point } \\
\text { prevalence of } 1.05 \text { per } 1000\end{array}$ & 0 & 0.002 & $\begin{array}{l}\text { Black children aged } 0-19 \\
\text { with type } 2 \text { diabetes }\end{array}$ & [37] \\
\hline $\begin{array}{l}\text { Odds ever of interacting } \\
\text { with the judiciary system as } \\
\text { a child (likelihood of one } \\
\text { violent crime arrest) }\end{array}$ & 0.099 & $\begin{array}{l}\text { Fixed prevalence throughout } \\
\text { childhood based on a point } \\
\text { prevalence of 9\% }\end{array}$ & 0.074 & 0.124 & $\begin{array}{l}\text { Low-income urban } \\
\text { Baltimore adolescents }\end{array}$ & {$[24]$} \\
\hline $\begin{array}{l}\text { Odds ratio good academic } \\
\text { achievement given child } \\
\text { received ParentCorps }\end{array}$ & 1.520 & & 1.000 & 2.430 & ParentCorps & [23] \\
\hline $\begin{array}{l}\text { Odds ratio good academic } \\
\text { achievement given child has } \\
\text { behavior problems }\end{array}$ & 0.229 & & 0.084 & 0.621 & ParentCorps & [23] \\
\hline $\begin{array}{l}\text { Odds Ratio child becomes } \\
\text { obese given they have low } \\
\text { self-regulation in pre-k }\end{array}$ & 3.846 & & 1.36 & 4.50 & ParentCorps & [4] \\
\hline $\begin{array}{l}\text { Odds Ratio child becomes } \\
\text { obese given they have low } \\
\text { self-regulation in pre-k and } \\
\text { received ParentCorps }\end{array}$ & 0.260 & & 0.080 & 0.865 & ParentCorps & [4] \\
\hline $\begin{array}{l}\text { Odds Ratio child becomes } \\
\text { obese given that they do } \\
\text { not have low self-regulation } \\
\text { and received ParentCorps }\end{array}$ & 1.000 & & 0.82 & 1.0 & ParentCorps & [4] \\
\hline $\begin{array}{l}\text { Odds Ratio child develops } \\
\text { behavior problems given } \\
\text { they received ParentCorps }\end{array}$ & 0.590 & & 0.41 & 0.85 & ParentCorps & {$[1,3,5]$} \\
\hline $\begin{array}{l}\text { Odds Ratio child develops } \\
\text { behavior problems given } \\
\text { low self-regulation }\end{array}$ & 3.800 & & 2.0 & 5.5 & $\begin{array}{l}\text { Urban children from Arizona } \\
\text { aged 55-97 months }\end{array}$ & {$[1,3,5,20]$} \\
\hline $\begin{array}{l}\text { Odds Ratio child graduates } \\
\text { from high school given they } \\
\text { have good academic } \\
\text { achievement }\end{array}$ & 1.335 & & 1.0 & 4.0 & $\begin{array}{l}\text { Children from Tennessee's Project } \\
\text { STAR evaluating graduation among } \\
\text { children in K-3 grade ( } 55.8 \% \text { free } \\
\text { lunch)hn }\end{array}$ & [22] \\
\hline
\end{tabular}


Table 1 Model inputs (Continued)

\begin{tabular}{|c|c|}
\hline \multicolumn{2}{|c|}{$\begin{array}{l}\text { Odds Ratio child graduates } \\
\text { from high school given they } \\
\text { abuse drugs }\end{array}$} \\
\hline \multicolumn{2}{|c|}{$\begin{array}{l}\text { Odds Ratio child graduates } \\
\text { from high school given they } \\
\text { have behavior problems }\end{array}$} \\
\hline \multicolumn{2}{|c|}{$\begin{array}{l}\text { Odds Ratio child abuses } \\
\text { drugs given they have } \\
\text { behavior problems }\end{array}$} \\
\hline \multicolumn{2}{|c|}{$\begin{array}{l}\text { Odds Ratio child with } \\
\text { obesity develops diabetes }\end{array}$} \\
\hline \multicolumn{2}{|c|}{$\begin{array}{l}\text { Odds Ratio child interacts } \\
\text { with judiciary system given } \\
\text { they abuse drugs }\end{array}$} \\
\hline \multicolumn{2}{|c|}{$\begin{array}{l}\text { Odds Ratio child interacts } \\
\text { with judiciary system given } \\
\text { they have behavior } \\
\text { problems }\end{array}$} \\
\hline \multicolumn{2}{|l|}{ Adult Specific } \\
\hline \multirow{3}{*}{$\begin{array}{l}\text { Odds of } \\
\text { developing } \\
\text { obesity per yr. } \\
(\mathrm{BMI}>30)\end{array}$} & $\begin{array}{l}\text { Age } \\
18-39\end{array}$ \\
\hline & $\begin{array}{l}\text { Age } \\
40-59\end{array}$ \\
\hline & Age $>60$ \\
\hline \multicolumn{2}{|c|}{$\begin{array}{l}\text { Odds of abusing drugs as } \\
\text { an adult per yr. (any alcohol } \\
\text { use/dependence) }\end{array}$} \\
\hline \multicolumn{2}{|c|}{$\begin{array}{l}\text { Odds of developing } \\
\text { diabetes as an adult per yr }\end{array}$} \\
\hline Odds of emplo & \\
\hline
\end{tabular}

Odds of employment

Odds Ratio adult with obesity develops diabetes

Odds of newly interacting with the judiciary system as an adult per yr. (likelihood to ever go to prison)

Odds of new psychiatric disorders as an adult per yr. (diagnosis of any mood disorder)

$\begin{array}{ll}\begin{array}{ll}\text { Odds of } \\ \text { cardiovascular } \\ \text { disease as an }\end{array} & \text { Age } \\ \text { adult, per yr } & \text { Age } \\ & 45-54 \\ & \text { Age } \\ & \text { 55-64 }\end{array}$

\subsection{9}

0.180

0.003

0.005

$-0.002$

0.007

0.002
0.584

0.826

US national sample adults over 18

surveying back on their childhood

[19]

$0.1 \quad 1.0$

Adolescents ages 15-20 with serious emotional disturbance, 38.2\% low

income, 39.5\% urban

1.0 $5.0 \quad$ New Zealand urban children

[51]

2.30

15.05

Study among urban New Zealand adolescents with alcohol misuse and juvenile offenses

1.300 6.375 Study among New Zealand males with childhood onset versus adolescent onset antisocial behavior

Constant incidence rate, based on 0 a point prevalence of $30 \%$ for ages 20-39; 39.5\% for ages 40-59; and $35.4 \%$ for age $>60$; assumed to be cumulative incidence for each age range.

0.064 The National Health and Nutrition Examination Survey 2007-2008, a representative sample of the US

0.01 population with measured heights and weights on 3281 children and

0.005 adolescents (2 through 19 years of age) and 719 infants and toddlers (birth to 2 years of age).

Constant incidence rate estimated

0.002

based on lifetime cumulative incidence of $26.6 \%$

0.013 Survey of psychiatric disorders among persons aged 15 to 54 years in the US noninstitutionalized civilian population

Constant incidence rate assumed based on cumulative incidence of 6.9 per 1000 (age 18-79)

0.006

CDC data on incidence of diagnosed diabetes among people aged 18-79

15.87 National unemployment rate from August 2013

prevalence of $927 \%$; assumed effect throughout adulthood (i.e., if employed stay employed and if unemployed stay unemployed from yr. to $y r$ )

Random digit phone survey of US adults aged $18 \mathrm{yrs}$. or older participating in Behavioral Risk Factor Surveillance System in 2001

0.005 Bureau of Justice data on lifetime likelihood of going to prison

based on lifetime cumulative incidence of $4.5 \%$

0

Constant incidence rate within age 0.005 groups estimated based on lifetime prevalence of mood disorder starting at age 18.

Constant incidence rate within each decade based on annual incidence rate

0.002

0.009

Survey of US residents aged 18 yrs. and older in National Comorbidity Survey Replication 2001-2003

0.006

0.006

NHLBI morbidity \& mortality chart book on cardiovascular, lung and blood diseases 
Table 1 Model inputs (Continued)

Age
$65-74$
Age
$75-84$
Age
85-94

Odds Ratio adult interacts with judiciary system given they abuse drugs

Odds Ratio adult interacts with judiciary system given interacting with the judiciary system in the last yr

Odds Ratio of employment given graduated high school

Odds Ratio of employment given interacting with the

Odds Ratio of using drugs given a history of abusing drugs in the last yr

Odds Ratio of obesity given obese in the last yr judiciary system in the last yr

0.028
0.052
0.075

2.300

car
Cardiovascular disease as the major health sequelae impacting life expectancy and quality of life calculated based on annual incidence rate of CVD in diabetes

Assume to be the same as risk of CVD in patients with diabetes

Any psychiatric disorder as the most significant health sequelae of drug abuse impacting life expectancy and quality of life; calculated based on lifetime cooccurrence of any mood disorder given alcohol abuse

Back calculated using the odds of interaction with judiciary within 3 years of release from prison

Back-calculated using Odds of 0.007 of non-persistence of obesity in adults with obesity. Assumed constant incidence rate, based on cumulative incidence risk of $14 \%$ over 21 year follow up (from age 17 to 38 ) and fixed prevalence after age 38 .

Inputs influencing costs

Inputs Cost Unit

(\$)

Annual drug abuse treatment cost

Annual drug abuse complication cost

Annual diabetes treatment cost

Annual diabetes complication cost (depression, dysthymia mania)

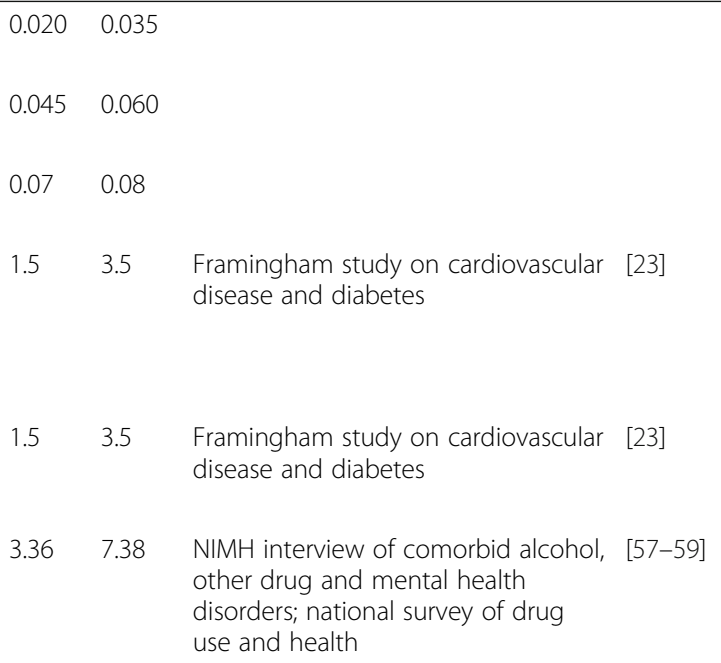

Prospective study of US criminal offenders substance use drug treatment and crime

Prospective study of US criminal offenders'recidivism

Bureau of labors statistics report of college enrollment and work activity of 2015 US high school graduates

Study of employment among adults released from NYC jails 
Table 1 Model inputs (Continued)

\begin{tabular}{|c|c|c|c|c|c|}
\hline Annual obesity treatment cost & $\$ 0$ & per person per year & 0 & 0 & {$[68]$} \\
\hline $\begin{array}{l}\text { Annual obesity complication } \\
\text { cost }\end{array}$ & $\$ 732$ & per person per year & 366 & 1098 & [43] \\
\hline $\begin{array}{l}\text { Annual judiciary system cost of } \\
\text { incarceration }\end{array}$ & $\$ 28,893$ & per person per year & 14,447 & 43,340 & {$[44]$} \\
\hline $\begin{array}{l}\text { Annual unemployment } \\
\text { opportunity cost }\end{array}$ & $\$ 33,160$ & per person per year & 16,580 & 49,740 & {$[45]$} \\
\hline $\begin{array}{l}\text { ParentCorps ongoing annual } \\
\text { costs per child }\end{array}$ & $\$ 500$ & per child & N/A & N/A & \\
\hline $\begin{array}{l}\text { ParentCorps capacity building } \\
\text { costs per school }\end{array}$ & $\$ 100,000$ & per school & N/A & N/A & \\
\hline \multicolumn{6}{|l|}{ Inputs influencing utilities } \\
\hline & $\begin{array}{l}\text { Inputs } \\
\text { (Utility) }\end{array}$ & & & & References \\
\hline Utility of having diabetes & 0.690 & & & & {$[69]$} \\
\hline $\begin{array}{l}\text { Utility of having complications } \\
\text { of diabetes }\end{array}$ & 0.350 & & & & [69] \\
\hline Utility of drug abuse & 0.670 & & & & {$[70]$} \\
\hline $\begin{array}{l}\text { Utility of having complications } \\
\text { of drug abuse }\end{array}$ & 0.600 & & & & {$[70]$} \\
\hline Utility of being obese & 0.710 & & & & {$[71]$} \\
\hline $\begin{array}{l}\text { Utility of having complications } \\
\text { of obesity }\end{array}$ & 0.500 & & & & [71] \\
\hline Utility of being in prison & 0.725 & & & & [72] \\
\hline
\end{tabular}

Note: In the model odds are adjusted using odds ratios and then converted to probabilities using the formula probability $=$ odds $/(1+$ odds $)$

\section{Outcomes}

Outcomes modeled were: 1) costs resulting from the development of the three disease states (i.e., obesity, diabetes, or drug abuse), health sequelae of these disease states (i.e., cardiovascular disease and psychiatric disorders), interaction with the judiciary system, and opportunity cost of unemployment; and 2) QALYs, which are affected by the development of the three disease states, their health sequelae, and interaction with the judiciary system.

\section{Assumptions}

As with all decision models, several assumptions were necessary. When there was uncertainty, we strove to be conservative, overestimating intervention costs and underestimating benefits.

\section{General data assumptions}

Most childhood inputs were based on data representing the demographics of youth living in urban areas in the United States [1-5, 18-37]. The following assumptions were made and tend to underestimate benefits and cost savings: The effect of behavior problems leading to drug abuse would manifest itself in the childhood phase only, and the health sequelae of diseases occurred only after youth became adults. As they were beyond the scope of these analyses, we did not consider the effect of graduation from high school on the likelihood of interaction with the judiciary system as an adult, the effect of poor health on employment, or the potential cost savings from ParentCorps due to decreased need for academic remediation, special education services, or mental health services during childhood and adolescence. Additionally, we assumed that the health sequelae with the greatest impact on life expectancy and quality of life was the development of cardiovascular disease for both diabetes and obesity, and further assumed that the likelihood of developing cardiovascular disease was the same for those with obesity and those with diabetes. This assumption was necessary due to the lack of data separating the likelihood of persons with obesity developing cardiovascular disease independent of diabetes. We did however consider the costs of other health sequelae in the total cost of diabetes and obesity health sequelae as described below.

\section{Utility assumptions}

"Utility" is a preference-weighted quality of life metric that is typically represented on a scale of 0 (death) to 1 (perfect health), and is used to calculate QALYs. To 
avoid double-counting when unemployment costs are represented, we assumed that there was no impact on utility of unemployment [38]. Utilities were assigned to the development of each of the three disease states, health sequelae of each disease, and for interaction with the judiciary system. For joint utilities having more than one disease or health sequelae, we used the minimum utility among the conditions [39].

\section{Cost assumptions}

We used the societal cost perspective in the model and focused on major cost drivers associated with ParentCorps implementation in a high-poverty, urban elementary school and the lowered costs associated with academic, behavior and health benefits from ParentCorps ultimately resulting in a lower likelihood of: 1) diabetes; 2) drug abuse; 3) interaction with the judiciary system; and 4) unemployment. Costs of health conditions were based on estimates from published reports [40-44]. We considered the costs of treatment for the disease state (obesity, diabetes, and drug abuse) separately from the cost of treatment for the health sequelae of the disease states (for diabetes this included costs of macrovascular disease, nephropathy, neuropathy, and retinopathy; for obesity this included the cost of treatment for hypertension, lipid disorders, coronary heart disease, and stroke; and for drug abuse this included the costs of treatment for drug abuse related psychiatric disorders).

Cost of incarceration was based on average annual judiciary system cost of incarceration by the US government [44]. The opportunity cost of unemployment was based on the hourly wage for non-farm workers [45].

ParentCorps costs were calculated by an independent consulting firm based on cost calculations from historical documentation of implementation in 18 highpoverty, urban schools participating in the two trials (2003-2011) and prospective documentation of implementation costs in 20 schools (2013-2014) (Wellspring Consulting LLC: Strategic Growth Plan for ParentCoprs in NYC, unpublished). Costs are per school and assume an average of 4 classrooms of 18 pre-k students $(n=72$ students). Children and families participate in programming during the pre-k year only. Costs include capacity building at the school-level (e.g., group-based training, individual coaching for teachers and school-based mental health professionals) for teachers and mental health professionals to implement ParentCorps with fidelity; and annual recurring costs associated with implementing ParentCorps programs (e.g., materials and tools for parents and children, meals for families and staff pay when programming is provided after school hours) with resources to serve all pre-k children (72 annually per school) and the majority $(\sim 80 \%)$ of their parents. The cost of capacity building (and implementation) over the first 2 years is $\$ 200,000$, and is conservatively estimated to last for 5 years before requiring substantial additional investment. The annual cost of implementation is $\$ 40,000$ (see appendix for table that breaks down these costs). Therefore, over a 5 -year period, it costs $\$ 320,000$ to serve $360(72 \times 5)$ pre-k students. This results in $\$ 888$ in program expenditures per student. In sensitivity analyses, we varied assumptions regarding these costs, including the number of pre-k students per school (best case: 100 students; worst case: 1 student), the percent of pre-k students with low levels of self-regulation (best case: $30 \%$ of students; worst case: $15 \%$ of students) and how long the investment in capacity building (training and coaching) would last (best case: 10 years; worst case: 1 year). We employed a conservative discount rate of $5 \%$, reflecting the idea that a cost or benefit in the future is valued less than the same cost or benefit today [39]. All costs are reported in 2015 \$US.

\section{Base case scenario}

In the base case scenario, we assumed 72 pre-k students per school and the initial capacity building investment lasting 5 years. We assumed that $25 \%$ of students entered pre-k with low levels of selfregulation as is typically found in high-poverty schools $[1-5,28]$.

\section{Sensitivity and threshold analyses}

Sensitivity analysis tests the degree to which the model's outcomes are affected by changes in data inputs across plausible ranges. Specifically, each input is changed individually across its plausible range to test the effect of this change on the model's outcomes. In addition, we performed threshold analyses for variables identified in one-way sensitivity analyses as having large effect on downstream costs and/or utility, in order to identify the thresholds at which estimates for these variables would change the model's key inferences for decision making, even if their plausibility was low.

\section{Results}

In the base case scenario, ParentCorps was both cost saving and improved health over the life course. ParentCorps saved $\$ 4387$ per person in healthcare, criminal justice, and productivity expenditures, after factoring in program costs (spending $\$ 888$ to save $\$ 5275$ per person over the longterm). ParentCorps increased each individual's qualityadjusted life expectancy by 0.27 QALYs.

\section{Validation}

We compared the model's predictions for life expectancy to the life expectancy reported for adults with obesity and those of normal weight from the 
National Death Index [46]. Our model estimates a life expectancy of 60.1 Life Years for an 18-year-old with obesity, which is within the range of life expectancy from the National Death Index which reports life expectancies for 18-year-old individuals with obesity to be 57.5 Life Years.

\section{Sensitivity analyses}

In one-way and multi-way sensitivity analyses, results regarding costs and benefits were highly stable, with ParentCorps remaining cost saving and improving health, even when varying nearly every model assumption across its plausible range. The diagrams depicted in Fig. 2
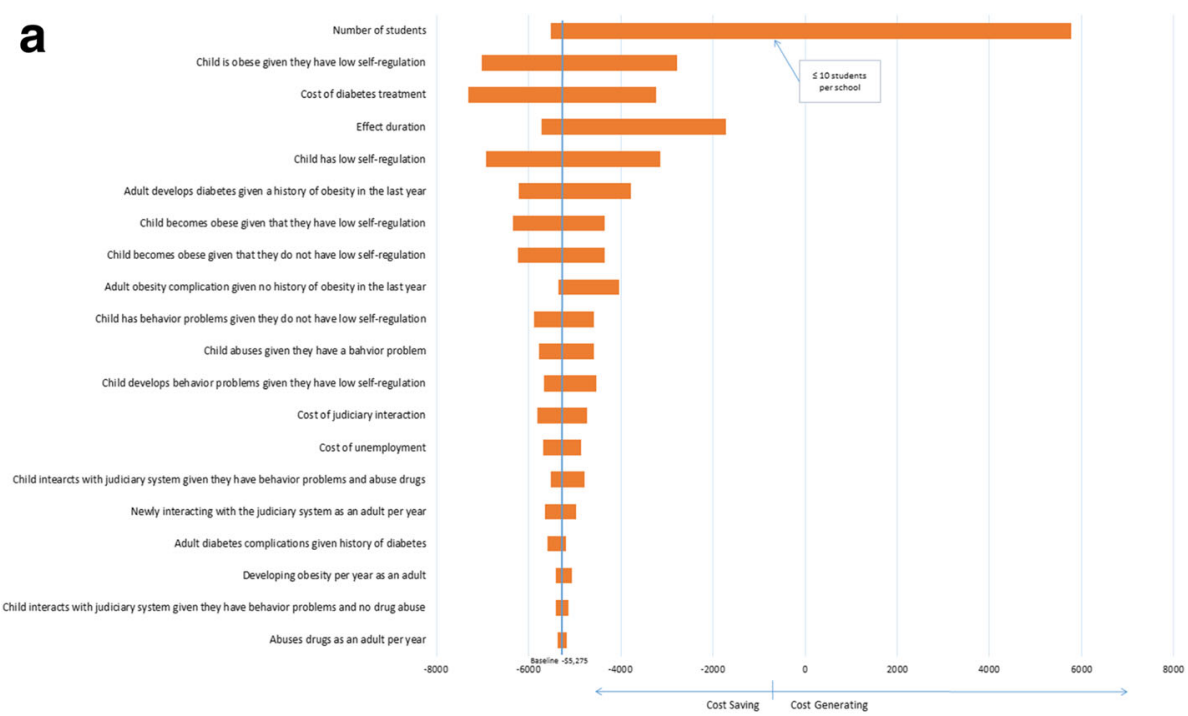

Difference in Cost (\$)

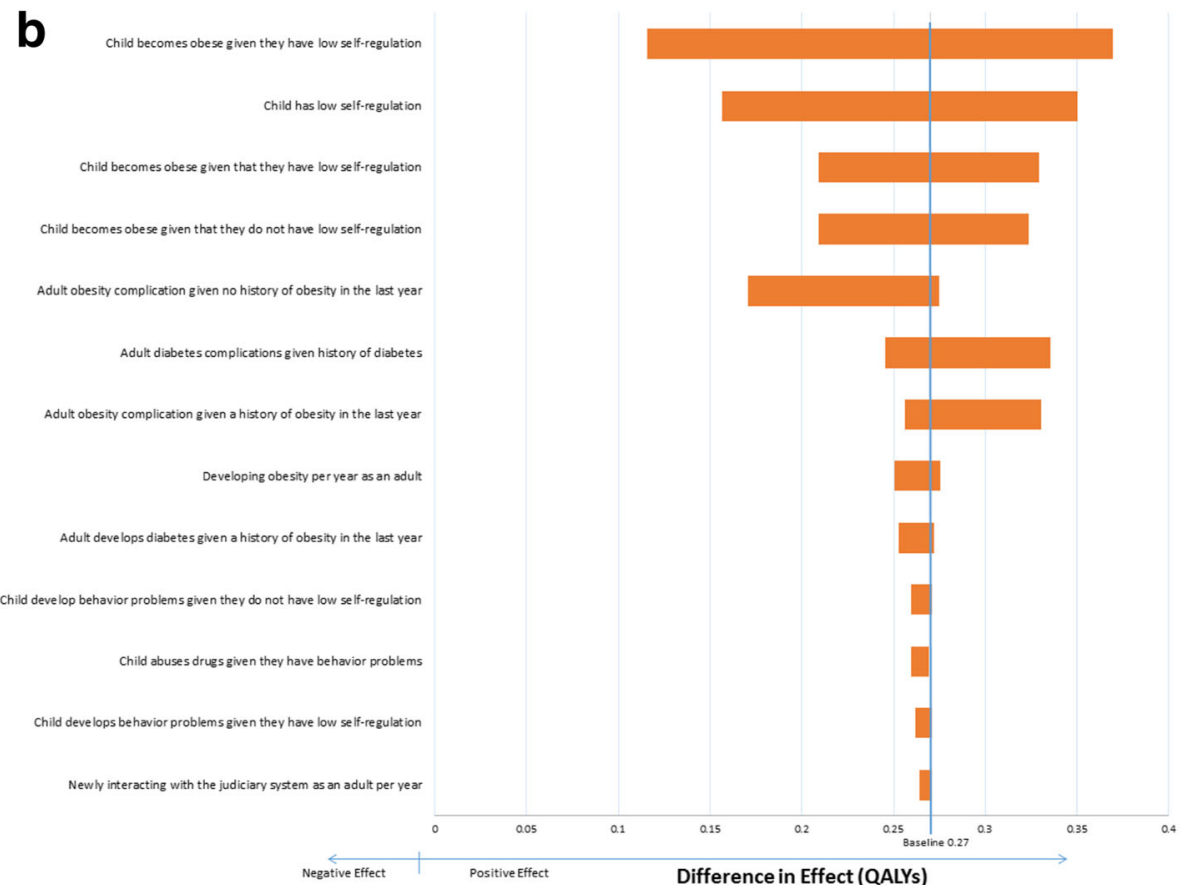

Fig. 2 Sensitivity analyses effect on costs (a) and QALYS (b). Sensitivity analyses to determine the effect on downstream costs (a) and QALYS (b) when model inputs were varied across plausible ranges (Table 1). The model inputs represented on the $y$-axis are probabilities. Wider bars indicate greater variability in estimated downstream costs or QALYs when the input was varied across its plausible range (i.e., the model was most sensitive to uncertainty around these inputs). a incorporates one threshold analysis in which we asked what price per student would result in ParentCorps no longer being cost saving 
report the change in the difference in cost (Fig. 2a) or QALYs (Fig. 2b) between ParentCorps enhanced pre-k programming versus standard pre-k programming when each of the model inputs was varied across its plausible range.

\section{Sensitivity analyses effect on cost (Fig. 2a)}

ParentCorps was cost saving under all circumstances, except under the scenario in which there were fewer than 10 pre-k students per school. The magnitude in cost difference between ParentCorps enhanced pre-k versus standard pre-k ranged from \$-10,297 (ParentCorps is cost saving) to $\$+53,062$ (ParentCorps is cost generating) when the number of pre-k students per school was varied from 100 to 1 student, respectively. Threshold sensitivity analysis found that ParentCorps would no longer be cost saving if the cost per student exceeded $\$ 6400 \quad(>7$ times the current cost estimate). ParentCorps still saved money if implemented in schools where only $10 \%$ of pre-k students had low levels of self-regulation (more typical of low poverty schools), when the pre-k program served at least 20 students.

When we varied the cost of ParentCorps, the prevalence of low self-regulation in pre-k and the number of students enrolled in the pre-k program, we found that even in the unlikely scenario in which the capacity building investment would last only 1 year instead of 5 years, intervention would continue to be cost saving in schools with more than 40 pre-k students, assuming that $35 \%$ of the students had low self-regulation; or in schools with 76 or more students, assuming that more than $15 \%$ had low self-regulation.

\section{Sensitivity analyses effect on QALYs (Fig. 2b)}

When all data inputs were varied across their plausible ranges, ParentCorps consistently increased QALYs, with magnitude ranging from 0.12 to 0.37 QALYs. The benefit originated principally from decreased behavior problems, obesity, diabetes, and drug abuse along with their health sequelae. In threshold analyses, there was no circumstance under which ParentCorps did not improve health and QALYs.

\section{Discussion}

ParentCorps delivered as an enhancement to pre-k programs in high-poverty, urban schools yields meaningful and sustained benefits across academic, behavior, and health domains through age 8. A mathematical model estimates that ParentCorps would save $\$ 4387$ per person over the life course. This estimate can be considered relative to cost savings figures generated by the Washington State Institute for Public Policy for two public health and preventive family-centered, early childhood interventions with the greatest benefits (i.e., Nurse Family Partnership $=\$ 8988$; Parents as Teachers $=\$ 6638$ ) as well as four parenting interventions for childhood behavior problems with the greatest cost savings (i.e., Triple $\mathrm{P}$ Positive Parenting Program $=\$ 2201$; Parent-child Interaction Therapy $=\$ 1704 ;$ Parent Management Training-Oregon Model $=\$ 1234$; and Incredible Years Parent Program $=\$ 1039$ ) [47]. The projected cost savings and increased quality-adjusted life expectancy are primarily attributable to ParentCorps' benefits for children at highest risk for problems based on entering pre-k with low levels of self-regulation. Benefits for this subgroup include impact on childhood obesity and predicted subsequent development of diabetes, and impact on childhood behavior problems and predicted subsequent interaction with the judiciary system, drug abuse, and unemployment. Notably, results underestimate the potential cost savings for the population of children enrolled in pre-k in highpoverty schools, and especially for this subgroup of children with low levels of self-regulation behavior because we did not model the cost savings in childhood and adolescence of decreased need for academic remediation, special education services or mental health services.

The long-term health benefit of ParentCorps delivered as an enhancement to pre-k programming in high-poverty, urban schools (potentially reaching all children enrolled in pre-k) was estimated to be 0.27 QALYs per person. For comparison, the United States Preventive Services Task Force recommends the universal screening of all newborns for phenylketonuria (PKU) and congenital hypothyroidism; these interventions are associated with adding 0.003 QALYs per person [48].

The most influential factors affecting the improvement in predicted QALYs for children in schools with ParentCorps, as tested in sensitivity analyses (Fig. 2b), were the prevalence of low self-regulation, the likelihood of children with low self-regulation developing obesity, the impact of ParentCorps on preventing obesity, and the likelihoods of health sequelae of diabetes and obesity in adulthood. Based on the assumptions in our model, early childhood family-centered interventions embedded in high-poverty schools, such as ParentCorps, that are successful in reaching, engaging and effectively supporting all families, especially the substantial subgroup of families of children with low self-regulation in pre-k, are likely to result 
in long-term population-level health benefits and cost savings.

Based on the potential for impacting three critical domains of child development (learning, behavior and health), and 8 years of implementation experiences outside of the RCTs, ParentCorps is currently being scaled in New York City (NYC) in partnership with the local Department of Education and the state Office of Mental Health. Although the intervention costs considered in the current study are based on experiences in schools within the RCTs as well as more recent implementation experiences outside of the trials (since 2009), capacity building and recurring implementation costs may increase or decrease as part of implementation in the context of a larger city-wide effort to provide high-quality pre-k programming at the population-level. As part of the implementation process, and in collaboration with city and state partners, capacity building and implementation costs will be calculated when implemented at scale. The impacts on childhood behavior, obesity and academic achievement considered in the current study simulation are based on outcomes from the two RCTs. As part of the ParentCorps strategic growth plan, two hybrid effectiveness/implementation randomized controlled trials (with more than 100 pre-k programs) are underway that will lead to a wealth of information on implementation quality and impact on children and families. At the completion of these studies, we plan to carry out a second cost-effectiveness study based on newly calculated implementation costs and outcomes when delivered at scale in schools serving diverse student populations. In NYC, there are more than 1850 pre$\mathrm{k}$ programs serving nearly 70,000 4-year-olds annually. Approximately half of these programs can be considered high-poverty. As one strategy to reach these pre-k programs, Brotman and colleagues have created a series of professional learnings for principals and teachers to support adoption of ParentCorps evidence-based strategies [49]. These professional learnings are also being studied in the context of randomized controlled trials that will consider costs and outcomes from ParentCorps professional learning relative to ParentCorps programming (as implemented in the original trials) and relative to other professional learning provided by the school district.

Our study has several limitations. An important limitation is that our findings represent the results of a simulation model which is constrained by the limitations of all such models. Most notably, the results depend on the data inputs which are derived from the mean values and plausible ranges from the best available evidence identified by the authors at the time of the study. For example, the variance of the impact of ParentCorps on preventing behavior problems and obesity may have been underestimated because estimates were derived from studies in which a small number of schools were randomized to each intervention condition. However, sensitivity analyses explored considerably smaller impacts and still found the model to be robust. In addition, all base-case childhood inputs were based on data representing the demographics of urban areas in the US, and therefore may not be generalizable to other populations. Although most assumptions were conservative, biased toward finding that ParentCorps was expensive and/or ineffective, the assumption that the likelihood of developing cardiovascular disease was the same in adults with either obesity or diabetes possibly overestimates the likelihood of developing cardiovascular disease in adults with obesity who do not have diabetes. A further limitation is that there are no longitudinal follow-up studies documenting the lifelong effect of early childhood interventions for obesity. Rather, we needed to make assumptions based on the cascading effect of shorter-term benefits of early childhood interventions persisting over time. Finally, to more fully capture the potential cost savings and impact of early intervention, future studies should consider more than one Markov state for childhood to account for new influences as children transition through adolescence, estimate cost savings related to educational and mental health services in childhood and adolescence, and consider the effect of graduation from high school on the likelihood of interacting with the judiciary system, employment and poor health.

\section{Conclusion}

When delivered as an enhancement to pre-k programs in high-poverty, urban schools, ParentCorps results in robust and sustained benefits in learning, behavior and health, especially among children with low levels of self-regulation early in life. Based on mathematical modeling, ParentCorps was estimated to save $\$ 4387$ per individual and increase each individual's quality-adjusted life expectancy by 0.27 QALYs. A systematic series of studies is currently underway to consider benefits and costs when ParentCorps is implemented at scale in high-poverty schools serving even more diverse student populations. ParentCorps has the potential to be both cost saving and health generating under nearly all assumptions, and holds promise as a population health approach with substantial return on investment. 


\section{Appendix}

Table 2 ParentCorps Costs [2005-2014]

\begin{tabular}{|c|c|c|c|}
\hline & Year 1 & Year 2 & Year 3+ \\
\hline Training & 15 trainees & $\begin{array}{l}3 \text { new } \\
\text { trainees }\end{array}$ & $\begin{array}{l}2 \text { new } \\
\text { trainees }\end{array}$ \\
\hline $\begin{array}{l}\text { ParentCorps FUNdamentals } \\
\text { (4-day) + Program Training } \\
\text { ( } 1 \text { day for Friends School/3 } \\
\text { days for Parenting Program) } \\
\text { ( } 56 \text { h training }+16 \text { h prep) }\end{array}$ & $\$ 12,000$ & $\$ 4000$ & $\$ 3000$ \\
\hline Manuals \& handouts & $\$ 2000$ & $\$ 975$ & $\$ 975$ \\
\hline School Staff Stipends & $\$ 5760$ & $\$ 1080$ & $\$ 1080$ \\
\hline Total - Training & 19,760 & $\$ 6055$ & $\$ 5055$ \\
\hline Implementation Materials & $\begin{array}{l}2 \text { group } \\
\text { series }\end{array}$ & $\begin{array}{l}3 \text { group } \\
\text { series }\end{array}$ & $\begin{array}{l}3 \text { group } \\
\text { series }\end{array}$ \\
\hline Brochures, Guides & $\$ 1500$ & $\$ 1500$ & $\$ 1500$ \\
\hline ParentCorps Program Materials & $\$ 3600$ & $\$ 3850$ & $\$ 3850$ \\
\hline Equipment & $\$ 2000$ & $\$ 0$ & $\$ 0$ \\
\hline Healthy Meals & $\$ 5830$ & $\$ 6850$ & $\$ 6850$ \\
\hline $\begin{array}{l}\text { School Staff Time (14 weeks } \times 3 \mathrm{~h} / \text { week } \\
\text { at per session rates) }\end{array}$ & $\$ 11,000$ & $\$ 11,000$ & $\$ 11,000$ \\
\hline Total Implementation Materials & $\$ 23,930$ & $\$ 23,200$ & $\$ 23,200$ \\
\hline Coaching & $\begin{array}{l}2 \text { group } \\
\text { series }\end{array}$ & $\begin{array}{l}3 \text { group } \\
\text { series }\end{array}$ & $\begin{array}{l}3 \text { group } \\
\text { series }\end{array}$ \\
\hline $\begin{array}{l}\text { Coaching for High-Quality } \\
\text { Program Implementation }\end{array}$ & $\$ 60,500$ & $\$ 60,500$ & $\$ 11,500$ \\
\hline Grand Total & $\$ 104,190$ & $\$ 89,755$ & $\$ 39,755$ \\
\hline
\end{tabular}

NOTE: Costs are calculated including data from 2005 to 2014 for capacity and implementation of ParentCorps in a large school (72 students per year; 4 classrooms). The costs below include capacity building and implementation. Capacity building costs includes ParentCorps FUNdamentals, and Training and Coaching for high-quality ParentCorps program implementation. Implementation assumes 2 series of the Parenting Programs in the first year (1 program delivered during the school day and 1 program during after-school hours with a parallel program for pre-k students) and 3 series in the second year and beyond ( 2 programs during the school day and 1 program during after-school hours). Each program serves 15 to 20 families. Implementation costs include materials, meals and school staff time for after-school programming and coaching. Implementation costs in year three and beyond are consistent with year two with the exception of reduced coaching time and costs

\section{Abbreviations}

pre-k: Pre-kindergarten; QALYs: Quality adjusted life years; RCTs: Randomized controlled trials

\section{Acknowledgements}

Not applicable.

\section{Funding}

New York State Office of Mental Health: C007885; to L M Brotman with subcontract to R S Braithwaite.

\section{Availability of data and materials}

All data generated or analyzed during this study are included in this published article. The model structure used during the current study is available from the corresponding author on reasonable request.

\section{Authors' contributions}

$\mathrm{NH}$ conceived of and designed the study, performed data collection, performed data analysis, drafted the article, and gave final approval of the version to be published; ERS performed data collection, performed data analysis, drafted the article, and gave final approval of the version to be published; MA performed data collection, performed data analysis, drafted the article, and gave final approval of the version to be published; KYH performed data collection, performed data analysis, and gave final approval of the version to be published; DK performed data collection, performed data analysis, and gave final approval of the version to be published; RSB conceived of and designed the study, performed data analysis, and gave final approval of the version to be published; LMB secured funding, contributed to the design of the study conceived of and designed the study, drafted the article, and gave final approval of the version to be published.

Ethics approval and consent to participate

All procedures performed in studies involving human participants were in accordance with the ethical standards of the NYU School of Medicine IRB. The need for ethics approval was waived.

\section{Consent for publication}

Not applicable.

\section{Competing interests}

The authors have no conflicts of interest to disclose. The authors have no financial relationships relevant to this article to disclose. Payments for the purchase of ParentCorps materials, training and technical assistance are made to the Department of Population Health at the NYU School of Medicine to cover costs for materials and faculty and staff salaries associated with training and technical assistance. Any revenue generated from these sales and trainings support further development and evaluation of ParentCorps.

\section{Publisher's Note}

Springer Nature remains neutral with regard to jurisdictional claims in published maps and institutional affiliations.

\section{Author details}

'Department of Medicine, Zucker School of Medicine at Hofstra/Northwell, 300 Community Drive, Manhasset, NY 11030, USA. ²Department of Population Health, New York University School of Medicine, 227 E. 30th St, New York, NY 10016, USA.

Received: 12 May 2017 Accepted: 27 September 2017

Published online: 10 October 2017

\section{References}

1. Brotman LM, Calzada E, Huang KY, Kingston S, Dawson-McClure S, Kamboukos D, Rosenfelt A, Schwab A, Petkova E. Promoting effective parenting practices and preventing child behavior problems in school among ethnically diverse families from underserved, urban communities. Child Dev. 2011;82(1):258-76.

2. Brotman LM, Dawson-McClure S, Calzada EJ, Huang KY, Kamboukos D, Palamar JJ, Petkova E. Cluster (school) RCT of ParentCorps: impact on kindergarten academic achievement. Pediatrics. 2013;131(5):e1521-9.

3. Brotman LM, Dawson-McClure S, Kamboukos D, Huang KY, Calzada EJ, Goldfeld K, Petkova E. Effects of ParentCorps in prekindergarten on child mental health and academic performance: follow-up of a randomized clinical trial through 8 years of age. JAMA Pediatr. 2016; 170(12):1149-55.

4. Brotman LM, Dawson-McClure S, Huang KY, Theise R, Kamboukos D, Wang J, Petkova E, Ogedegbe G. Early childhood family intervention and longterm obesity prevention among high-risk minority youth. Pediatrics. 2012;129(3):e621-8.

5. Dawson-McClure S, Calzada E, Huang KY, Kamboukos D, Rhule D, Kolawole B, Petkova E, Brotman LM. A population-level approach to promoting healthy child development and school success in low-income, urban neighborhoods: impact on parenting and child conduct problems. Prev Sci. 2015;16(2):279-90 
6. Dodge KA, Malone PS, Lansford JE, Miller S, Pettit GS, Bates JE. A dynamic cascade model of the development of substance-use onset. Monogr Soc Res Child Dev. 2009;74(3):vii-119.

7. Kellam SG, Brown CH, Poduska JM, lalongo NS, Wang W, Toyinbo P, Petras $\mathrm{H}$, Ford C, Windham A, Wilcox HC. Effects of a universal classroom behavior management program in first and second grades on young adult behavioral, psychiatric, and social outcomes. Drug Alcohol Depend. 2008; 95(Suppl 1):S5-S28.

8. Whitaker RC, Wright JA, Pepe MS, Seidel KD, Dietz WH. Predicting obesity in young adulthood from childhood and parental obesity. N Engl J Med. 1997;337(13):869-73.

9. Trasande L. How much should we invest in preventing childhood obesity? Health Aff (Project Hope). 2010;29(3):372-8.

10. Ma S, Frick KD. A simulation of affordability and effectiveness of childhood obesity interventions. Acad Pediatr. 2011;11(4):342-50.

11. Wang LY, Denniston M, Lee S, Galuska D, Lowry R. Long-term health and economic impact of preventing and reducing overweight and obesity in adolescence. J Adolesc Health. 2010;46(5):467-73.

12. TreeAge Pro 2015, R1.0. https://www.treeage.com. Accessed 2 June 2016.

13. Drummond MF, Sculpher MJ, Claxton K, Stoddart GL, Torrance GW. Methods for the economic evaluation of health care programmes. New York: Oxford University Press; 2015.

14. DerSimonian R, Laird N. Meta-analysis in clinical trials. Control Clin Trials. 1986;7(3):177-88.

15. Evans JL, Tsui Jl, Hahn JA, Davidson PJ, Lum PJ, Page K. Mortality among young injection drug users in San Francisco: a 10-year follow-up of the UFO study. Am J Epidemiol. 2012;175(4):302-8.

16. Morbidity \& Mortality: 2012 Chart Book on Cardiovascular, Lung, and Blood Diseases. https://www.nhlbi.nih.gov/files/docs/research/2012 ChartBook_508.pdf. Accessed 20 Oct 2014.

17. Tsai SP, Donnelly RP, Wendt JK. Obesity and mortality in a prospective study of a middle-aged industrial population. J Occup Environ Med. 2006;48(1):22-7.

18. Dawson-McClure S, Brotman LM, Theise R, Palamar JJ, Kamboukos D, Barajas RG, Calzada EJ. Early childhood obesity prevention in low-income, urban communities. J Prev Interv Community. 2014;42(2):152-66.

19. Breslau J, Miller E, Joanie Chung WJ, Schweitzer JB. Childhood and adolescent onset psychiatric disorders, substance use, and failure to graduate high school on time. J Psychiatr Res. 2011;45(3):295-301.

20. Eisenberg N, Cumberland A, Spinrad TL, Fabes RA, Shepard SA, Reiser M, Murphy BC, Losoya SH, Guthrie IK. The relations of regulation and emotionality to children's externalizing and internalizing problem behavior. Child Dev. 2001;72(4):1112-34.

21. Fergusson DM, Horwood LJ, Ridder EM. Show me the child at seven: the consequences of conduct problems in childhood for psychosocial functioning in adulthood. J Child Psychol Psychiatry. 2005;46(8):837-49.

22. Finn JD, Gerber SB, Boyd-Zaharias J. Small classes in the early grades, academic achievement, and graduating from high school. J Educ Psychol. 2005;97(2):214-23.

23. Kannel WB, McGee DL. Diabetes and cardiovascular disease. The Framingham study. JAMA. 1979;241(19):2035-8.

24. Ludwig J, Duncan GJ, Hirschfield P. Urban poverty and juvenile crime: evidence from a randomized housing-mobility experiment. Q J Econ. 2001;116(2):655-79.

25. Wagner MM. Outcomes for youths with serious emotional disturbance in secondary school and early adulthood. Futur Child. 1995;5(2):90-112.

26. Young TK, Dean HJ, Flett B, Wood-Steiman P. Childhood obesity in a population at high risk for type 2 diabetes. J Pediatr. 2000;136(3):365-9.

27. Blum RW, Beuhring T, Shew ML, Bearinger LH, Sieving RE, Resnick MD. The effects of race/ethnicity, income, and family structure on adolescent risk behaviors. Am J Public Health. 2000;90(12):1879-84.

28. Campbell SB. Behavior problems in preschool children: a review of recent research. J Child Psychol Psychiatry. 1995;36(1):113-49.

29. Carter AS, Wagmiller RJ, Gray SA, McCarthy KJ, Horwitz SM, Briggs-Gowan MJ. Prevalence of DSM-IV disorder in a representative, healthy birth cohort at school entry: sociodemographic risks and social adaptation. J Am Acad Child Psychiatry. 2010;49(7):686-98.

30. Ogden CL, Carroll MD, Kit BK, Flegal KM. Prevalence of childhood and adult obesity in the United States, 2011-2012. JAMA. 2014;311(8):806-14.

31. Moffitt TE, Caspi A, Harrington H, Milne BJ. Males on the life-coursepersistent and adolescence-limited antisocial pathways: follow-up at age 26 years. Dev Psychopathol. 2002;14(1):179-207.
32. Mokdad AH, Ford ES, Bowman BA, Dietz WH, Vinicor F, Bales VS, Marks JS. Prevalence of obesity, diabetes, and obesity-related health risk factors, 2001. JAMA. 2003;289(1):76-9.

33. National Center for Education Statistics. http://nces.ed.gov/quicktables/ result.asp?SrchKeyword=general+academic+achievement\&topic=All. Accessed 16 Sept 2013.

34. Thorpe LE, List DG, Marx T, May L, Helgerson SD, Frieden TR. Childhood obesity in New York City elementary school students. Am J Public Health. 2004;94(9):1496-500.

35. State Level Overall and Low-Income ACGR Rates. http://eddataexpress.ed. gov/state-tables-main.cfm. Accessed 6 June 2014.

36. Go AS, Mozaffarian D, Roger VL, Benjamin EJ, Berry JD, Borden WB, Bravata DM, Dai S, Ford ES, Fox CS, et al. Executive summary: heart disease and stroke statistics-2013 update: a report from the American Heart Association. Circulation. 2013;127(1):143-52.

37. Liese AD, D'Agostino RB Jr, Hamman RF, Kilgo PD, Lawrence JM, Liu LL, Loots B, Linder B, Marcovina S, Rodriguez B, et al. The burden of diabetes mellitus among US youth: prevalence estimates from the SEARCH for diabetes in youth study. Pediatrics. 2006;118(4):1510-8.

38. Gold MR, Siegel JE, Russell LB. Cost-effectiveness in health and medicine. New York: Oxford University Press; 1996.

39. Dale W, Basu A, Elstein A, Meltzer D. Predicting utility ratings for joint health States from single health States in prostate cancer: empirical testing of 3 alternative theories. Med Decis Mak. 2008;28(1):102-12.

40. Caro JJ, Ward AJ, O'Brien JA. Lifetime costs of complications resulting from type 2 diabetes in the U.S. Diabetes Care. 2002;25(3):476-81.

41. Dall TM, Zhang Y, Chen YJ, Quick WW, Yang WG, Fogli J. The economic burden of diabetes. Health Aff (Millwood). 2010;29(2):297-303.

42. Dickey B, Azeni H. Persons with dual diagnoses of substance abuse and major mental illness: their excess costs of psychiatric care. Am J Public Health. 1996;86(7):973-7

43. Finkelstein EA, Ruhm CJ, Kosa KM. Economic causes and consequences of obesity. Annu Rev Public Health. 2005;26:239-57.

44. Annual Determination of Average Cost of Incarceration. https:// federalregister.gov/a/2013-06139. Accessed 9 May 2014.

45. Average hourly and weekly earnings of production and nonsupervisory employees on private nonfarm payrolls by industry sector, seasonally adjusted. http://www.bls.gov/news.release/empsit.t24.htm. Accessed 20 Oct 2014.

46. Muennig $P$, Lubetkin $E$, Jia $H$, Franks $P$. Gender and the burden of disease attributable to obesity. Am J Public Health. 2006;96(9):1662-8.

47. Benefit-Cost Results. http://wsipp.wa.gov/BenefitCost. Accessed 21 July 2017

48. Carroll AE, Downs SM. Comprehensive cost-utility analysis of newborn screening strategies. Pediatrics. 2006;117(Supplement 3):S287-95.

49. Dawson-McClure S, Calzada EJ, Brotman LM. Engaging parents in preventive interventions for young children: working with cultural diversity within lowincome, urban neighborhoods. Prev Sci. 2017;18(6):660-70.

50. Merikangas KR, He JP, Burstein M, Swanson SA, Avenevoli S, Cui L, Benjet C, Georgiades K, Swendsen J. Lifetime prevalence of mental disorders in U.S. adolescents: results from the National Comorbidity Survey Replication-Adolescent Supplement (NCS-A). J Am Acad Child Adolesc Psychiatry. 2010;49(10):980-9.

51. Fergusson DM, Lynskey MT, Horwood L. Alcohol misuse and juvenile offending in adolescence. Addiction. 1996;91(4):483-94.

52. Kessler RC, McGonagle KA, Zhao S, Nelson CB, Hughes M, Eshleman S, Wittchen HU, Kendler KS. Lifetime and 12-month prevalence of DSM-III-R psychiatric disorders in the United States. Results from the National Comorbidity Survey. Arch Gen Psychiatry. 1994;51(1):8-19.

53. Crude and Age-Adjusted Incidence of Diagnosed Diabetes per 1,000 Population Aged 18-79 Years, United States, 1980-2014. https://www.cdc. gov/diabetes/statistics/incidence/fig2.htm. Accessed 20 Dec 2016

54. Current Employment Statistics - CES (National). http://www.bls.gov/ces. Accessed 20 Oct 2014.

55. Bureau of justice Statistics Special Report: Lifetime Likelihood of Going to State or Federal Prison. http://bjs.gov/content/pub/pdf/Llgsfp.pdf. Accessed 20 Oct 2014

56. Kessler RC, Berglund $\mathrm{P}$, Demler $\mathrm{O}$, Jin $\mathrm{R}$, Merikangas KR, Walters EE. Lifetime prevalence and age-of-onset distributions of DSM-IV disorders in the National Comorbidity Survey Replication. Arch Gen Psychiatry. 2005;62(6):593-602.

57. Kessler RC, Berglund P, Demler O, Jin R, Koretz D, Merikangas KR, Rush AJ Walters EE, Wang PS. The epidemiology of major depressive disorder: results 
from the National Comorbidity Survey Replication (NCS-R). JAMA. 2003; 289(23):3095-105.

58. Regier DA, Farmer ME, Rae DS, Locke BZ, Keith SJ, Judd LL, Goodwin FK. Comorbidity of mental disorders with alcohol and other drug abuse. Results from the Epidemiologic Catchment Area (ECA) Study. JAMA. 1990;264(19):2511-8.

59. Hedden SL. Behavioral health trends in the United States: results from the 2014 national survey on drug use and health; 2015.

60. Gottfredson DC, Kearley BW, Bushway SD. Substance use, drug treatment, and crime: an examination of intra-individual variation in a drug court population. J Drug Issues. 2008;38(2):601-30.

61. Langan PAP, Levin DJP. Recidivism of Prisoners Released in 1994. Fed Sentencing Rep. 2002;15(1):58-65.

62. College Enrollment and Work Activity of 2015 High School Graduates. https://www.bls.gov/news.release/hsgec.nro.htm. Accessed 20 Dec 2016

63. Freudenberg N, Daniels J, Crum M, Perkins T, Richie BE. Coming home from jail: the social and health consequences of community reentry for women, male adolescents, and their families and communities. Am J Public Health. 2008;98(9 Suppl):S191-202.

64. Dawson DA, Grant BF, Stinson FS, Chou PS, Huang B, Ruan WJ. Recovery from DSM-IV alcohol dependence: United States, 2001-2002. Addiction. 2005:100(3):281-92.

65. Wang LY, Gutin B, Barbeau P, Moore JB, Hanes J Jr, Johnson MH, Cavnar M, Thornburg J, Yin Z. Cost-effectiveness of a school-based obesity prevention program. J Sch Health. 2008;78(12):619-24.

66. Nicklas JM, Huskey KW, Davis RB, Wee CC. Successful weight loss among obese U.S. adults. Am J Prev Med. 2012;42(5):481-5.

67. French MT, McGeary KA, Chitwood DD, McCoy CB. Chronic illicit drug use, health services utilization and the cost of medical care. Soc Sci Med. 2000;50(12):1703-13.

68. Finkelstein EA, Trogdon JG, Cohen JW, Dietz W. Annual medical spending attributable to obesity: payer-and service-specific estimates. Health Aff (Millwood). 2009;28(5):w822-31.

69. Unden AL, Elofsson S, Andreasson A, Hillered E, Eriksson I, Brismar K. Gender differences in self-rated health, quality of life, quality of care, and metabolic control in patients with diabetes. Gend Med. 2008;5(2):162-80.

70. Kraemer KL, Roberts MS, Horton NJ, Palfai T, Samet JH, Freedner N, Tibbetts $N$, Saitz R. Health utility ratings for a spectrum of alcohol-related health states. Med Care. 2005:43(6):541-50.

71. Sendi P, Brunotte R, Potoczna N, Branson R, Horber FF. Health-related quality of life in patients with class II and class III obesity. Obes Surg. 2005;15(7):1070-6.

72. Chong CA, Li S, Nguyen GC, Sutton A, Levy MH, Butler T, Krahn MD, Thein $\mathrm{HH}$. Health-state utilities in a prisoner population: a cross-sectional survey. Health Qual Life Outcomes. 2009;7:78.

\section{Submit your next manuscript to BioMed Central and we will help you at every step:}

- We accept pre-submission inquiries

- Our selector tool helps you to find the most relevant journal

- We provide round the clock customer support

- Convenient online submission

- Thorough peer review

- Inclusion in PubMed and all major indexing services

- Maximum visibility for your research

Submit your manuscript at www.biomedcentral.com/submit 